\title{
DESEJO E AMOR PELA REVOLUÇÃO: MARX E ESPINOSA
}

\section{Resumo}

Marcos F. de Paula48

Até que ponto seria possível explicar as tensões políticas do presente por meio do recurso aos afetos espinosanos, notadamente o amor? Este trabalho busca, por meio de uma aliança entre as ideias de Espinosa e de Marx, (re)pensar as possibilidades correntes da mobilização de um afeto em específico: o amor pela revolução, ou a alegria contida no ato de desejar mudanças para si e para a sociedade, sendo esta hoje um corpo político cindido, isto é, dividido e marcado pela contrariedade entre suas partes.

Palavras-chave: desejo, amor, revolução, política, afetos.

\section{DESIRE AND LOVE FOR REVOLUTION: MARX \& SPINOZA}

\begin{abstract}
This paper aims, using Marx and Spinoza's ideas as a starting point, (re)think the actual possibility of social and individual engagement in a web of affections that leads to the "love of revolution", i.e, the joy contained in an act of desiring changes for ourselves and for society corpus, marked by a major disruption in presente time. Therefore, that is the question that drives this paper: is it possible to understand political tensions nowadays by affections (notably Love), in a Spinozan style?
\end{abstract}

Keywords: desire, love, revolution, politics, affections

A enorme passeata percorreu a cidade, aumentando aos poucos e empunhando mais estandartes com dizeres bordados a ouro. Dois velhos camponeses, os corpos encurvados de tanto trabalho acumulado, caminhavam de mãos dadas, os rostos iluminados por uma alegria infantil. "Bem", disse um deles, "agora é que eu quero ver eles tomarem de volta as nossas terras!" Nas proximidades do Smolny, a Guarda Vermelha estava alinhada nos dois lados da rua, esfuziante de felicidade. O outro camponês idoso se dirigiu a seu camarada: "Não me sinto cansado", disse ele, "andei o dia inteiro como se estivesse voando!".

John Reed, Dez dias que abalaram o mundo.

Mas, se a revolução é desejável, por que não seria possível? Não existe nenhuma lei na história que nos garanta o advento de uma revolução, assim como não existe nenhuma que nos proteja de um retorno à barbárie. Mas também não existe nenhuma que impeça para sempre a possibilidade de uma revolução desejável.

P. Dardot e C. Laval, Comum: ensaio sobre a revolução no século XXI.

\footnotetext{
${ }^{48}$ Professor Doutor na Universidade Federal de São Paulo (UNIFESP).E mail: marcosfdepaula@yahoo.fr
} 
1.

O século de Espinosa não conheceu esse afeto político específico, que aqui vamos nomear amor pela revolução. Não que no XVII, como antes dele, revoluções já não estivessem em curso. O próprio racionalismo moderno, que alcança seu auge no tempo de Espinosa, era então um acontecimento revolucionário. Mas não havia em Descartes, Espinosa, Leibniz, Kepler ou Newton uma consciência e um desejo propriamente revolucionários ${ }^{49}$. No final do século seguinte, já muitos dos revolucionários franceses estarão cientes de que o que estão fazendo é uma revolução.

É verdade que revolutio é uma palavra que já existia pelo menos desde meados do século XV. Foi talvez a obra de Nicolau Copérnico (1473-1543), De revolutionibus orbium colestium, que popularizou o termo revolução. Em Sobre a revolução das esferas celestes, no entanto, o termo tem um sentido astronômico preciso: refere-se, como sabemos, à trajetória que os planetas percorrem em torno do sol. Descrevendo um círculo perfeito, como acreditava Copérnico, ou uma elipse, como demonstrará Johannes Kepler (1571-1630) no século XVII, a trajetória do planeta o faz retornar sempre aos mesmos pontos. Retornar se diz revolvo, revolvere, em latim. Voltar ao ponto inicial, recomeçar sempre dos mesmos pontos para voltar aos mesmos lugares, é o sentido rigorosamente oposto àquele que revolução passará a ter trezentos anos mais tarde. Os revolucionários burgueses ainda podiam sonhar em transformar radicalmente a sociedade retomando, de certa forma, os grandes ideais da democracia ou da bela república dos antigos gregos e romanos, mas não será esta a ideia de revolução sonhada e desejada, por exemplo, por anarquistas e socialistas, a partir do século XIX, quando enfim emergem as classes trabalhadoras, engendradas no mesmo movimento de constituição das

\footnotetext{
${ }^{49}$ Afirmação válida mesmo se considerarmos as hipóteses de Antonio Negri sobre a "anomalia" de Espinosa na Holanda do XVII. Negri considera, por um lado, que Espinosa "representa a mais alta consciência produzida pela revolução científica e pela revolução do Renascimento"; por outro lado, considera Espinosa produtor de uma "filosofia do porvir"; e acrescenta: "O primeiro é um produtor da ordem do capitalismo, o segundo talvez seja o promotor, o autor de uma constituição futura" (NEGRI, 1993, p. 31). Em ambos os casos, Espinosa não está produzindo um pensamento sob o signo da teleologia: não está pensando para mudar, para revolucionar, ainda que o filósofo certamente cogitasse as implicações transformadoras do seu pensamento e seu caráter "subversivo" (isto é, oposto a ordem vigente); tanto assim que Espinosa terá o cuidado (caute!) de não mais publicar seus trabalhos após a circulação perigosamente ruidosa do Tratado teológico-político, de 1667, confiando a amigos a publicação póstuma de textos com a Ética e o Tratado Político - cuidado que certamente exprime a consciência do caráter revolucionário de seu pensamento. As possíveis transformações implicadas no pensamento de Espinosa eram certamente desejadas por ele - "o amor para com uma coisa eterna e infinita", transformação radical do ânimo, por exemplo, é muito "de se desejar" e "se há de buscar com todas as forças" (voltaremos a isso), afirma ele no Tratado da Emenda do Intelecto (TIE, §10). Mas nesse desejo não está contida a ideia de uma transformação radical, histórica e coletiva, pensada como projeto, filosófico e político, enquanto tal, ainda que o filósofo estivesse produzindo uma "filosofia do porvir". Se, como quer Negri, Espinosa é o mais "revolucionário" dos pensadores do XVII, é pela radicalidade do seu pensamento, por sua dimensão subversiva, tanto filosófica quanto ética e política.
} 
camadas burguesas industriais, como mostraram Marx e Engels, já em O manifesto do partido comunista $^{50}$, às vésperas da Primavera dos Povos, em 1848.

Precisamente a entrada em cena das classes laboriosas, antes de tudo os operários das indústrias, irá engendrar o desejo de revolução, incialmente disforme, difuso, confuso, inscrito sob o signo da indignação e da revolta, mas que aos poucos ganhará forma, clareza e organização, à medida que Marx, Engels e tantos outros revolucionários forem construindo a ideia no seio mesmo dos movimentos operários. O desejo de revolução - que encontra expressão na elaboração teórica e na organização política - é um desejo de resistência diante das condições de miséria e degradação das camadas trabalhadoras, algo do que Engels oferecera um importante retrato já em A situação da classe trabalhadora, publicada em 1845, três anos antes do Manifesto. Desse desejo nasce o afeto político que estamos chamando de amor pela revolução.

Se tomarmos a definição de amor, em Espinosa, o amor como alegria concomitante à ideia de uma causa exterior ${ }^{51}$, de que maneira poderíamos definir o amor pela revolução? Em termos muito simples, trata-se de uma alegria engendrada pela percepção de que os trabalhadores podem transformar radicalmente a realidade na qual se encontram, e que desejam erradicar; essa alegria é acompanhada da ideia da própria potência dos trabalhadores como causa; ela engendra, portanto, um amor da classe trabalhadora por si mesma. O amor pela revolução é, assim, a alegria da classe trabalhadora conjuntamente à ideia de sua potência transformadora.

Mas na base desse amor, como veremos, está o desejo de transformação, que o precede e o engendra.

2.

Todas as obras de Marx, Engels, Lênin, Trostky e outros grandes revolucionários, em todas as partes do mundo, não foram outra coisa senão o gesto de mostrar aos trabalhadores não só a necessidade da transformação radical e estrutural da sociedade, como também o fato de que eram eles mesmos, os trabalhadores, os únicos verdadeiros agentes dessa transformação histórica. A ideia de revolução nasce da resistência às tristezas - dominação, exploração, miséria, destruição, violência, opressão - engendradas necessariamente pelo modo de produção capitalista. Nascida da tristeza, e contra ela, a ideia de revolução é no

\footnotetext{
50 "Na mesma proporção em que a burguesia, ou seja, o capital, se desenvolve, desenvolve-se também o proletariado, a classe dos trabalhadores modernos, que só podem viver se encontrarem trabalho, e só encontram trabalho na medida em que este aumenta o capital" (MARX; ENGELS, 1982, p. 99).

51 “O Amor é a Alegria conjuntamente à ideia de causa externa”. E III, AD 6.
} 
entanto uma alegria, porque mostra aos dominados, explorados e oprimidos que eles são capazes de se constituírem como sujeitos históricos da transformação que de algum modo desejam, porque não desejam a tristez ${ }^{52}$.

A resistência à opressão e à exploração, como diversos exemplos históricos o mostram, pode exprimir-se em revoltas ou rebeliões, levantes ou sublevações. Qualquer que seja seu nome, em todos os casos trata-se de ações coletivas que se opõem às instâncias do poder dominante e opressor, em geral visibilizado no Estado. Mas tais ações podem se caracterizar como atos de violência mais ou menos desorganizados, mais ou menos desorientados, tornando mais difícil tarefa de modificar as estruturas mesmas que engendram as tristezas contra as quais elas se opõem. Quando e onde a indignação é desorganizada, a revolta, a rebelião ou o levante malogram em suprimir as causas do mal que buscam combater. Elas podem derrubar o tirano, mas não eliminam as estruturas nas quais se assenta a tirania, para usar uma velha imagem moderna. São formas de luta que podem e de fato tendem a permanecer no terreno do embate concreto e imediato, carecendo de "teoria", isto é, de uma compreensão menos difusa sobre as causas e sobre os fins que seria preciso alcançar para pôr fim às causas, às determinações da situação contra a qual lutam. Não que neste campo as ações sublevantes não sejam capazes de engendrar transformações. Pelo contrário: seu conjunto perfaz todo um processo histórico revolucionário que pode dar lugar a determinados momentos de intensificação das mudanças - e são esses momentos que podemos chamar de revoluções.

A revolução, afirmava Claude Lefort, não é um "acontecimento absoluto" e as revoluções que tiveram lugar na história não são meros episódios de uma "Revolução Universal", nos intervalos dos quais só haveria repetição histórica, "reprodução das relações sociais". Todas as revoltas, todos os levantes e sublevações anteriores podem culminar num episódio de intensificação do processo revolucionário em curso, e são portanto momentos sem os quais as revoluções conhecidas não poderiam vir à luz. Há um “cordão umbilical”, dizia Lefort, "que liga a revolução à revolta"53.

A ideia de revolução que foi se constituindo a partir do século XIX, com a tradição iniciada com Marx e Engels, não se erigiu contra utopias, revoltas, rebeliões e levantes. Ela parte desses gestos históricos para pensar uma determinada maneira de transformar radicalmente o modo de vida dos homens, para imprimir outro rumo à história, e isso com

\footnotetext{
${ }^{52}$ A essa afirmação, a ontologia espinosana oferece bases sólidas, ao propor uma teoria do desejo humano (conatus) como expressão certa e determinada da potência infinita da Natureza (Deus). Voltaremos a esse ponto. Ver também ensaio " $x$ ".

${ }^{53}$ LEFORT, Claude, op. cit., p. 160-161.
} 
algum grau de consciência, mais sobre o que buscar - isto é, desejar - do que como fazer. Contudo, a ideia de revolução não pretende ser a plena consciência histórica, uma ideia que, de posse de um telos claro, objetivo, devesse ser aplicada durante a luta dos dominados contra os dominantes. Nem consciência plena, nem tampouco roteiro prévio da ação política coletiva, a ideia de revolução é antes um gesto "teórico" com fins claramente práticos, para pôr os trabalhadores em marcha contra as determinações de sua condição não mais aceita. Elaborada contra a injustiça e a exploração do homem pelo homem sob o capitalismo moderno, a ideia de revolução pode ser vista, não como tentativa de organizar a luta contra as tristezas do capitalismo, mas como gesto político movido pelo desejo de despertar os trabalhadores para um outro modo possível de vida ${ }^{54}$.

Ocorre que, espinosanamente, toda resistência contra tristeza é uma forma de alegria, e toda alegria tende a engendrar um amor, porque quase sempre o afeto de alegria vem acompanhado da ideia de sua causa, real ou imaginária ${ }^{55}$. A ideia de revolução, nesse caso, engendra um amor de resistência: uma alegria nascida contra as tristezas do modo de produção capitalista, uma alegria constituída na luta contra elas e movida pelo desejo de transformação radical deste mundo num mundo melhor, realmente justo, sem a luta entre dominantes e dominados, entre exploradores e explorados; uma alegria acompanhada da ideia dos próprios trabalhadores como causa da transformação. E é certo também, pela mesma lógica afetiva, que são amados, de alguma maneira, os líderes revolucionários vistos como condutores do movimento transformador da vida dos trabalhadores.

\section{3.}

Todo o problema é saber como e em que condições históricas o desejo e o amor pela revolução podem surgir. Não é difícil ver que os meros fatos da exploração, da injustiça, da desigualdade e da opressão, embora necessários, não são suficientes para desencadear nem o desejo, nem o amor pela revolução, e muito menos uma consciência revolucionária. Em todas as revoluções do século XX, havia muito mais em jogo, os contextos foram sempre muito

\footnotetext{
${ }^{54}$ Não se trata de que as aspirações de orientar a luta dos trabalhadores não estejam envolvidas na ideia de revolução, mas o desejo de revolução precede as tentativas de orientação e organização das classes trabalhadoras e as determina. Antes de organizar a mudança, é preciso deseja-la.

${ }^{55}$ A alegria, por definição, é tão-somente a passagem a uma perfeição maior, isto é, a uma potência maior de agir e, no modo humano, igualmente de pensar. Mas a alegria é um fruir da existência que não necessariamente envolve, concomitantemente, a ideia da causa dessa alegria, o que constitui propriamente o amor. O amor é um afeto mais complexo do que a alegria, no sentido de que além do próprio gozo do aumento da potência, ele envolve a ideia da causa desse aumento. Só os seres mais complexos, como os humanos e alguns outros animais, são capazes de amar. Nestes, entretanto, é praticamente impossível que haja alegria sem o afeto de amor, dada a própria complexidade de seus corpos-mentes.
} 
complexos, situações singulares carregadas de uma pluralidade enorme de fatores. De qualquer forma, uma coisa é certa: as revoluções, ou melhor, os momentos de intensificação do processo revolucionário, só foram possíveis porque, por diversas causas históricas, um movimento revolucionário, mais ou menos consciente e de algum modo organizado, foi uma vez colocado em marcha. Isso significa que homens e mulheres foram historicamente determinados a colocar em questão a própria história de sua condição social. E, colocando-a em questão, foram levados pelo desejo de transformá-la radicalmente numa outra coisa; foram levados a desejar uma mudança total das estruturas determinantes, porque, de alguma maneira, ainda que difusa ou confusa, apreenderam os nexos causais que configuravam necessariamente a paisagem do modo de vida no qual se encontravam; foram enfim levados ao desejo coletivo de instituir um outro modo de vida. A tradição revolucionária inicia assim a concepção de uma outra potência possível da multitudo. E essa concepção é ela mesma produto e produtora de um desejo coletivo de instituir uma vida nova, um modo novo de produzir a vida, as relações entre os homens e entre estes e a natureza; um outro modo de produção, na linguagem de Marx.

Um novo modo de vida: novum institutum, dizia Espinosa no prólogo do Tratado da Emenda do Intelecto ${ }^{56}$. A comparação não é de modo algum sem sentido. Ela é boa sob vários aspectos. Tendo sido determinado, numa luta entre a vida e a morte, a pôr em questão a história de sua própria experiência afetiva, o que o meditante deseja acima de tudo não é nada menos do que uma transformação radical de sua própria vida, para alcançar nada menos do que uma alegria de outra ordem, "contínua e suma alegria", a felicidade. E o que vai se operar, então, é uma verdadeira revolução de si: revolução conceitual e prática, cognitiva e afetiva, filosófica e política ${ }^{57}$. Mas não é justamente isso o que pretendiam Marx, Engels e todos os seus seguidores? A ideia de revolução é a concepção não utópica de uma "felicidade

\footnotetext{
${ }^{56} T I E, \S 3$.

${ }^{57}$ Ética e política são dimensões intrinsecamente entrelaçados num mesmo movimento de transformação, na filosofia espinosana. Já no Prefácio do Tratado Teológico-Político, a conexão entre desejo excessivo, superstição e poder político: comumente, os homens são movidos pelos bens incertos da fortuna; eles os "cobiçam desenfreadamente"; mas como são bens incertos, eles são movidos por esperança e medo, mais do que pela razão; se tudo ocorre sempre favoravelmente, sentir-se-iam fortes, seguros de si, mas muitas vezes não é assim e, então, encontram-se quase sempre num estado de ânimo em que estão dispostos a acreditar seja lá no que for: superstição. Espinosa cita então uma passagem de a História de Alexandre Magno de Quinto Cúrcio: "Na verdade (como se prova pelo que já dissemos e como Cúrcio observou, no Livro IV, cap. X), não há nada mais eficaz do que a superstição para governar as multidões", concluindo em seguida: "Por isso é que estas são facilmente levadas, sob a capa da religião, ora a adorar os reis como se fossem deuses, ora a execrá-los e a detestá-los como se fossem para todo o gênero humano" (TP, Pref., p. 7 [7]). Se a Ética pode ser lida como um verdadeiro contradiscurso frente aos sistemas supersticiosos de pensamento, é porque a consequência da compreensão da ontologia do necessário são, a um só tempo, a moderação do desejo, a instauração de desejos racionais, a redução ao máximo do medo e a total supressão da superstição - precisamente os antídotos contra as velhas e sempre atuais formas de governar as multidões...
} 
coletiva" possível, assim como o novum institutum é a ideia de uma felicidade igualmente real, possível, não utópica, que o meditante é levado a conceber, para escapar da servidão e, no limite, da morte, nascida da experiência afetiva do ânimo doente. O percurso que vai da servidão à liberdade, no entanto, embora possível, é árduo, dirá Espinosa mais tarde, ao final de sua Ética...

O que torna um tal percurso árduo é talvez menos o trilhá-lo do que o começar a percorrê-lo. O mais difícil talvez seja o momento da conversão, o momento da transformação do desejo em desejo de uma nova vida ${ }^{58}$. No plano da experiência afetiva singular do indivíduo, que é aquele em que se situa a narrativa do meditante no prólogo do TIE, o que torna a decisão pela transformação tão difícil são precisamente os bens que o indivíduo goza e dos quais ele ainda não é capaz de se desvencilhar: riqueza e avareza (avaritia); prazeres do corpo (libido) e fama ou glória (gloria), aderem ainda ao corpo-mente do meditante, embora ele já esteja se transformando:

[...] conquanto eu percebesse essas coisas com a mente de maneira tão clara, no entanto, eu não podia, por isso, depor toda avareza, prazer e gloria (TIE, $\S 10)$.

Se a passagem à felicidade é difícil, é justamente porque determinadas alegrias aderem ao corpo e à mente, de tal forma que o indivíduo não vê como abandoná-las, no presente, em prol de um bem futuro e por isso mesmo incerto. Será preciso que o meditante experimente a alegria da transformação já operando, para que àqueles bens seja contraposto a alegria da nova vida, uma alegria tanto maior quanto mais o meditante sabe, nesse momento de sua narrativa, que aqueles bens eram na verdade males certos, alegrias que sempre traziam escondidas certas tristezas como efeitos indiretos desses bens vivenciados sob o signo da paixão e do desejo excessivo. A disposição em meditar sobre a nova vida já se põe, assim, como uma alegria, na medida em que o próprio ato meditativo afasta o meditante das más

\footnotetext{
${ }^{58}$ Conversão não traz, aqui, nenhum sentido religioso. A escolha desse termo é apenas para marcar o caráter radical da transformação do desejo. Foi pensando em uma passagem da "Introdução" do filósofo Lívio Teixeira à sua tradução do TIE (Tratado da Reforma da Inteligência), que escolhemos utilizá-lo. Ao comentar a diferença entre o caráter das meditações em "As regras para a direção do espírito", de Descartes, e as meditações do TIE, Lívio Teixeira escreve: "É uma emendatio, uma correção da inteligência. Não se trata de regras de bem pensar para serem aplicadas à investigação da verdade, como, por exemplo, as 'Regulae ad directionem ingenii', de Descartes, mas de uma meditação sobre a natureza do pensamento que nos leve, como pela mão, a uma sorte de conversão intelectual, a uma radical mudança de ponto de vista que permitirá ver todas as coisas, inclusive o homem e seu destino, na total unidade do Ser Perfeitíssimo [...]" TEIXEIRA, Lívio. "Introdução", in: ESPINOSA, Baruch de. Tratado da Reforma da Inteligência. Trad. de L. Teixeira. 2a . ed. São Paulo: Martins Fontes, 2004, p. $\mathrm{x}$.
} 
alegrias até aí vivenciadas:

Unicamente isso eu via: que enquanto a mente voltava-se para perto desses pensamentos, ao mesmo tempo afastava-se daquelas coisas e seriamente pensava no novo instituto; o que foi para mim de grande consolo. Pois via que aqueles males não eram de tal condição que não aceitassem ceder a remédios $(T I E, \S 11)$.

Alegrias que eram causas indiretas de tristezas cedem lugar à alegria intrínseca ao próprio ato de meditar sobre uma nova vida, que justamente neste momento se mostra real e possível, isto é, não utópica. E essa nova maneira de viver se mostra realizável no próprio tempo, ou melhor, na duração de uma experiência afetiva em ato:

$\mathrm{E}$, conquanto no início esses intervalos fossem raros e durassem por um espaço de tempo extremamente exíguo, no entanto, depois que o verdadeiro bem mais e mais se me dava a conhecer, esses intervalos foram mais frequentes e mais longos $(T I E, \S 11)$.

Mas há ainda um outro motivo pelo qual o novo modo de vida se mostra real e concreto. É que a experiência do meditante vai levá-lo à compreensão de que aqueles bens incertos, portadores de males certos, não precisam ser abandonados: eles só precisam ocupar o lugar que lhes cabe na nova experiência afetiva, o lugar de meios para se alcançar o "sumo bem", isto é, a felicidade, a "contínua e suma alegria":

[...] principalmente depois que vi que a aquisição de dinheiro ou o prazer e a glória são obstáculos apenas enquanto são buscados por si mesmos e não como meios para outras coisas; mas, em verdade, se são buscados como meios, então terão moderação e não obstarão nem um pouco, mas sim, ao contrário, muito conduzirão ao fim pelo qual são buscados, como mostraremos no seu devido lugar (TIE, §11).

Nesse momento, toda a experiência se reordena, uma nova ordem afetiva é instaurada. Muito embora a felicidade - transformação radical de si - não tenha ainda sido plenamente alcançada, a revolução de si já está em curso, porque já se sabe que o que se deseja, acima de tudo, é uma alegria de outra ordem, e o caminho para a sua realização. Esse caminho, Espinosa tratará de mostrá-lo claramente apenas muitos anos depois da redação do Tratado da Emenda do Intelecto, ao redigir sua grande obra prima, a Ética. Mas a revolução espinosana já estava em curso. Caberá à Ética, a partir de uma “ontologia do necessário" (Parte I), expor e demonstrar uma ontologia do corpo-mente (Parte II) e uma ciência dos afetos (Partes III e IV), resultando numa ética da liberdade e da felicidade (Parte V). Com Espinosa, a felicidade 
deixa de ser uma utopia; com Marx, é a revolução que deixa de ocupar esse lugar no imaginário político.

\section{4.}

O que a revolução de $s i^{59}$, do Tratado da Emenda, nos ensina sobre a ideia de revolução social ou, antes, de revolução socialista, sobre a ideia de emancipação humana e política, proposta por toda a tradição marxiana, desde meados do século XIX?

Lênin dizia que não há práxis revolucionária sem teoria revolucionária. Poderíamos acrescentar que não há teoria revolucionária sem o desejo de revolução. A teoria revolucionária é a meditação assídua sobre a possibilidade da transformação radical do modo de vida social. Mas ela já é o resultado do desejo de transformação, o efeito de uma “conversão" política. No entanto, a emergência do desejo de revolução, isto é, de instituição de uma nova vida, contra a velha ordem do modo de vida capitalista, é talvez tão difícil quanto a transformação do desejo em desejo de felicidade. Há aqui uma infinidade de fatores pelos quais poderíamos explicar tamanha dificuldade. São fatores de toda ordem, histórica, cultural, social, política e econômica. Mas sem dúvida, no capitalismo, em que a esfera econômica domina quase inteiramente as outras dimensões da vida, os principais motivos encontram-se no campo da circulação de mercadorias, incluindo a força de trabalho.

De um lado, o problema da força de trabalho, central na economia política de Marx, é de suma importância para compreendermos o quanto é difícil desejar, pensar e passar a uma outra ordem social de vida. Sabemos no que se transforma a força de trabalho, sob o capitalismo: como quase tudo, ela se torna uma mercadoria, com valor nominal determinado num mercado de trabalho, o que só se tornou possível num relativamente longo processo de desapropriação dos meios de produção e de desenvolvimento da propriedade privada. $\mathrm{Na}$ verdade, o trabalho humano se torna a principal mercadoria, decisiva na acumulação de capital e na concentração da renda, na medida em que é a única mercadoria cuja especificidade é produzir valor (novas mercadorias) no momento mesmo da realização de seu "valor de uso": comprada e vendida no mercado de trabalho, a mercadoria-trabalho é a única que, ao ser consumida, produz novas mercadorias; é da parte produzida por ela, mas não paga ao trabalhador, que os donos dos meios de produção extraem seus lucros. O problema é que,

\footnotetext{
59 Em 1966, o filósofo Lívio Teixeira, seguindo um pouco as traduções correntes para o francês do Tratado da Emenda do Intelecto, optou pelo título Tratado da Reforma da Inteligência. Na apropriação que estamos fazendo aqui deste texto de juventude de Espinosa, não seria um disparate traduzir seu título por Tratado da Revolução do Intelecto, como nos sugeriu certa vez um outro grande espinosano, Cristiano Rezende, atualmente professor da faculdade de filosofia da Universidade Federal de Goiás.
} 
desprovidos de todo o resto e tendo unicamente a possibilidade da venda da força de trabalho por um salário determinado, os trabalhadores se veem presos na economia de mercado, numa relação de dependência vital (ou vendem sua força de trabalho ou morrem). É o que Frédéric Lordon chamou de rapport salarial, a relação salarial, forma por excelência de relação social que constitui o modo de vida capitalista. E ela é tanto mais central quanto mais se impõe com uma força praticamente incontornável. Lordon chega a afirmar que a relação salarial impõe aos trabalhadores uma espécie de servidão não voluntária: o trabalhador é obrigado a aderir a essa ordem de produção e circulação de mercadorias, precisamente porque não encontra outra maneira de exercer o seu conatus, isto é, o seu esforço em perseverar na existência. Mas a servidão não voluntária do capitalismo engendra, ao mesmo tempo, o desejo de permanecer nessa ordem, nesse mesmo modo de vida, porque a relação salarial dá ao trabalhador o meio a moeda, o dinheiro - com o qual ele realiza o desejo de aquisição das mercadorias de que ele necessita para viver e sobreviver, isto é, para realizar o desejo essencial, originário e incontornável de perseverar na existência. E, assim, o próprio salário e o próprio dinheiro, a moeda, tornam-se objeto de um desejo. Compreende-se, então, o quanto é difícil para o trabalhador, na ordem comum de sua existência, até mesmo pensar num outro modo de vida.

De outro lado, entretanto, o salário, o dinheiro recebido, proporciona, até certo ponto, e para uma parte considerável dos trabalhadores, as alegrias do consumo das mercadorias socialmente necessitadas. E o fator decisivo é que essas mercadorias acabam por constituírem-se em prazeres que aderem, alegrias que o capital também produz, é preciso dizer, em meio a todas as tristezas que lhes são próprias. Esse ponto é importante. Nós sabemos que Marx descobre o segredo do capital ao sair da "esfera barulhenta" da circulação de mercadorias e penetrar a esfera da produção ${ }^{60}$, precisamente ali onde se realiza a compra, venda e uso de uma mercadoria específica, a força de trabalho, causa material e formal de tudo o que se produz. E, no entanto, ele parte da análise da mercadoria, magistralmente realizada, como se sabe, no capítulo I da primeira Seção de $O$ Capital. Não vamos retomar aqui a análise de Marx. Basta-nos lembrar que esse primeiro capítulo ensinou a todos nós que, no capitalismo, toda a vida se passa justamente na superfície, aí onde as mercadorias ganham vida, onde, como que enfeitiçadas (fetiche), elas parecem ir ao mercado sozinhas para se trocarem. É nessa esfera barulhenta que toda a sociabilidade se constitui, antes de tudo. Nela,

\footnotetext{
60 "Sob o severo chicote do dinheiro, o mundo fica enraivecido. Para trazer à luz seus prodígios, é preciso, diz Marx no fim da segunda seção [do Livro I do Capital], dar as costas à gritaria do mercado, abandonar 'essa esfera barulhenta onde tudo se passa na superfície', descer ao 'laboratório secreto da produção', surpreender e desvelar 'a produção da mais-valia, esse grande segredo da sociedade moderna'" - escreve Daniel Bensaïd. Cf. BENSAÏD, D. Marx, o intempestivo. Rio de Janeiro: Civilização Brasileira, 1999, p.334.
} 
os trabalhadores vendem sua força de trabalho, recebem por isso, compram uma pequena parte do que produzem, a circulação de pessoas e objetos se complexifica, as relações sociais se adensam em torno da propriedade privada e os poderes da ordem se constituem para garanti-la. Tudo isso é permeado pela forma mercadoria que, simultaneamente ao direito - o Estado de Direito -, torna-se finalmente a forma por excelência da sociabilidade capitalista ${ }^{61}$.

Ocorre que no capitalismo a mercadoria vai se tornando cada vez mais uma imagem. Como se trata, nele, de produzir, não valores de uso, mas antes de tudo valores de troca, aquilo que nele se produz não é produzido para atender as necessidades reais de seres humanos concretos, como acreditava Adam Smith, mas sim para ser vendido, trocado, a necessidade - para a satisfação da qual se requer valores de uso, coisas úteis - ficando sempre em segundo plano. É por isso que o capitalismo desenvolveu tão bem a forma imagem que recobre a ser da mercadoria, que precisa ser escoada, trocada, vendida, pouco importando se terá ou não uma utilidade real. É assim que uma parte considerável do custo da produção de uma mercadoria refere-se à embalagem que a reveste: pagamos em boa medida pela imagem, pela aparência da mercadoria. A mercadoria, portanto, não pode ser só uma coisa útil: ela precisa ser antes de tudo uma imagem que desperte desejo por ela, um desejo que pouco ou nada leve em conta a utilidade real da mercadoria, seu valor de uso. Útil, em Espinosa, se diz bom. Contudo, não é porque algo é bom que o desejo: é porque o desejo que ele me aparece como bom ( $E$ III, prop. 9, esc.). Ao despertarem desejos, as imagens já não precisam ser úteis, isto é, boas: o desejo se encarrega de torná-las boas, mesmo que elas não o sejam.

Os fios que tecem a trama da sociabilidade capitalista são as mercadorias, um conjunto de imagens em circulação no qual estão enredados os nossos desejos. O imaginário social, no capitalismo, é constituído por uma gigantesca coleção de mercadorias, que tem como correlato uma complexa rede de imagens. Por isso não importa se consumimos realmente tais mercadorias recobertas pela película imagética: o capitalismo desenvolve o tempo todo a própria forma imagem, sob o signo da imprensa, das vitrines, da publicidade, dos celulares, do rádio, da televisão e, por fim, de uma rede mundial de computadores conectados entre si - e, com tudo isso, aquilo que não consumimos realmente, podemos consumir sob a própria forma da imagem, realização fantasmática do desejo. Não são, portanto, apenas as determinações objetivas - as estruturas econômicas, a relação salarial, o sistema político - que nos mantêm presos na trama da sociabilidade capitalista. O desejo, diz Espinosa, é o próprio esforço em perseverar na existência, ele é a essência do humano ( $E$ III, prop. 9, escol.; AD 1); e, assim,

\footnotetext{
${ }^{61}$ Ver Pachukanis, Teoria Geral do Direito e Marxismo.
} 
capturado na trama da circulação de mercadorias-imagens, o desejo vai constituir ele mesmo o fio que percorre a trama e a mantém. É por isso que é tão difícil sair desse complexo tecido que nos enreda a todos. Muitas vezes, não o podemos, como o mostra a relação salarial, que institui uma relação de dependência vital; mas, frequentemente, sequer desejamos fugir dessa gaiola de ferro (iron cage), para utilizar a imagem de um liberal crítico e resignado como Max Weber $^{62}$. Sob o capitalismo, perseveramos na servidão do desejo dos bens que nos prendem no circuito do imaginário coletivo da circulação de mercadorias, esse mundo da superfície que esconde as relações de produção, mas onde acontece a experiência imediata do próprio gozo desses bens, as alegrias do capital. A emergência do desejo de revolução, de instituição de um novo modo de vida, é tanto mais difícil quanto mais todas as tristezas do capital vêm acompanhadas das alegrias que o capital também proporciona. Potência e impotência são forças contrárias mas coexistentes, no capitalismo, e essa ambivalência dificulta a emergência do desejo negador do próprio capitalismo. O problema é ainda maior porque onde há alegria, há quase sempre amor. Há, então, até certo ponto, o que poderíamos chamar de "amor pelo capital", nascido do gozo das alegrias, isto é, dos bens que ele coloca em circulação, ainda que boa parte dos trabalhadores só possa gozar desses bens sob o signo evanescente do consumo de imagens, elas mesmas um produto entre outros...

5.

Estamos falando de um desejo e de um amor historicamente determinados. Poderíamos então perguntar se as democracias liberais contemporâneas não favorecem a emergência do desejo de transformação e, consequentemente, do amor pela revolução, pela transformação radical. A resposta a essa pergunta é tanto mais importante quanto ela talvez permita pensar os limites disso que hoje, em toda parte, parece ser um consenso, a democracia.

As democracias, sobretudo as atuais, não eliminam a divisão social entre "grandes e povo" (grandi e popolo), para falar nos termos de Maquiavel ${ }^{63}$. Mantendo as estruturas políticas que sustentam um determinado modo de produção econômica, as democracias liberais, sob o capitalismo, concorrem para aprofundar a divisão social e a luta entre os que

\footnotetext{
${ }^{62}$ Cf. WEBER, Max. A ética protestante e o "espírito" do capitalismo. São Paulo: Companhia das Letras, 2003, p.86

63 "Pois em todas as cidades", escreve Maquiavel em $O$ príncipe, "existem esses dois humores diversos que nascem da seguinte razão: o povo não quer ser comandado nem oprimido pelos grandes, enquanto os grandes desejam comandar e oprimir o povo". Cf. MAQUIAVEL, Nicolau. O príncipe. São Paulo: Martins Fontes, 2008, p. 43 (cap. IX).
} 
desejam mais democracia (o "povo") e os que desejam menos democracia (os "grandes"). São dois "humores" distintos, diria Maquiavel, e dois desejos contraditórios. Uma contradição que ganha expressão nos gestos de violência institucional (ou apoiada pelo Estado), contra toda tentativa de mudança que represente ameaça às estruturas de dominação dos "grandes" sobre o "povo". Assim, toda vez que gestos de liberdade de expressão ou de ações e movimentos políticos são considerados excessivos, porque teriam ultrapassado os limites da ordem pública e legal, os Estados mostram sua força e violência "legítimas", impedindo que conquistas sejam realizadas e a democracia seja aprofundada. A força dos que querem menos se contrapõe ao desejo dos que querem mais democracia, e a estes é imposta uma determinada violência, na mesma medida em que se lhes determinam os limites de sua ação, com o que sua potência política não é expandida. Com isso, fica praticamente impossibilitada qualquer tentativa de transformação das estruturas sociais, políticas e econômicas.

Mas não é só a reação organizada dos grupos sociais dominantes o que impede a transformação. Uma parte considerável da sociedade - a maior parte, quase sempre simplesmente não deseja mudanças bruscas ou rupturas não previstas. Eis por que uma revolução é sempre vista como algo que ameaça o funcionamento normal (cotidiano, comum) das estruturas sociais e políticas. No limite, revolução significa transformar tudo, mudar radicalmente, e não é evidentemente por acaso que todas as grandes revoluções deram lugar inicialmente a períodos de "guerra civil" ou eventos muito próximos disso ${ }^{64}$. Ela é por excelência a instauração ou a tentativa de instauração do novo; rompe o tempo e abre, no presente, caminhos para um futuro que no entanto é incerto. E, contudo, por mais que a ideia de um "novo mundo", uma nova realidade, contenha a promessa de um mundo melhor, ela é sempre uma ameaça diante do já instituído, no qual os cidadãos se sentem seguros, não obstante todos os problemas que nele possam estar presentes. Um presente repleto de problemas é ainda mais seguro do que um futuro promissor, mas incerto. Por isso mesmo, a atitude que poderíamos chamar de "conservadora" é o normal, a regra, a "ordem comum" da vida política ${ }^{65}$.

Em termos espinosanos, não é difícil compreender a causa desse "conservadorismo" quase "natural”. De fato, no capítulo XVI do Tratado Teológico-político, identificando direito e potência, Espinosa considera que os homens criam a política precisamente para melhor

\footnotetext{
${ }^{64}$ Dar algum exemplo aqui, a Revolução Russa de 1917, mas encontrar outros exemplo.

${ }^{65}$ Aqui poderíamos estabelecer uma diferença importante entre reacionários e conservadores. Os reacionários são todos aqueles que não hesitam em empregar o uso da força e da violência para manter a ordem vigente e contra as ameaças (reais ou imaginárias) de transformação; os conservadores definem-se antes de tudo pelo desejo de conservação. Os primeiros são mais movidos pelo ódio; os segundos, pelo medo.
} 
exercer sua potência natural, pela qual são determinados a buscar tudo o que é ou lhes parece ser útil para manterem-se na existência ${ }^{66}$. Dotados naturalmente de desejos e paixões tristes e alegres, os homens temem "a guerra de todos contra todos", como queria Hobbes, mas também conservam a esperança de uma união que é sentida como melhor e mais útil à conservação de todos. O desejo de evitar a guerra é um desejo triste, posto que nasce do medo, mas o desejo de união dos conatus é um desejo alegre, que nasce da esperança. Alegria e tristeza são modalidades primárias da variação de potência, do conatus, isto é, do desejo humano $^{67}$. O esforço em perseverar na existência determina que busquemos eliminar ou contornar os obstáculos a ele (como a guerra, vista como a grande ameaça à vida, isto é, como dinâmica da morte), e criar meios para efetivá-lo da melhor maneira possível (como a união pacífica dos conatus, percebida como melhor e mais útil). Dessa dinâmica passional dos conatus nasce a política. Mas medo e esperança são afetos instáveis. Instabilidade e variação são as marcas de toda e qualquer paixão, e por isso os homens são determinados a criar, como escreve Chauí, "um conjunto de leis e instituições" comuns, que convenham "à índole e aos costumes da multitudo, a fim de estabilizar suas paixões, limitá-las e moderá-las" ${ }^{\text {"68 }}$. Sem isso não há paz nem segurança, que são, afinal, os motivos últimos para os quais a vida política é instituída. É essa paz e essa segurança que os homens querem conservar; são elas que eles temem perder.

No entanto, "paz" e "segurança" podem ser conquistadas e mantidas sobre os

\footnotetext{
66 “É, com efeito, evidente que a natureza, considerada em absoluto, tem direito a tudo o que está em seu poder", escreve Espinosa, "isto é, o direito da natureza se estende até onde se estende a sua potência, pois a potência da natureza é a própria potência de Deus, o qual tem pleno direito a tudo. Visto, porém, que a potência universal de toda a natureza não é mais do que a potência de todos os indivíduos em conjunto, seguese que cada indivíduo tem pleno direito a tudo o que está em seu poder, ou seja, o direito de cada um estendese até onde se estende a sua exata potência. E, uma vez que é lei suprema da natureza que cada coisa se esforce, tanto quanto esteja em si, por perseverar no seu estado, , sem ter em conta nenhuma outra coisa a não ser ela mesma, resulta que cada indivíduo tem pleno direito a fazê-lo, ou seja, [...] a existir e agir conforme está naturalmente determinado". Espinosa, Tratado Teológico-político, Cap. XVI. Cf. ESPINOSA, Baruch. Tratado Teológico-político. Trad. Diogo Pires Aurélio. São Paulo: Martins Fontes, 2003, p. 234, Cap. XX. Mas o que tanto o TTP quanto o TP (Tratado Político) irão demonstrar é que no "estado de natureza", em que impera o isolamento, a solidão, o medo e a violência, tal direito natural é nulo, porque, como dizia Hobbes, porque aí todos podem tudo, ninguém pode nada. Os homens se unem para ter mais potência do que teriam isoladamente, e essa união é o que constitui a política. Em Espinosa, como se sabe, ela não se dá meramente por um contrato ou um pacto (embora o termo esteja presente no TTP), mas por uma experiência ontológica fundada num dinâmica afetiva da tristeza (medo da guerra, medo da morte) e da alegria (esperança de paz e segurança). Voltaremos a isso mais adiante.

${ }^{67}$ No escólio da Proposição 11 da Parte III da Ética, após definir alegria e tristeza como paixões pelas quais a mente passa a uma perfeição maior ou menor, Espinosa escreve: “[...] o que seja o Desejo, expliquei no escólio da Proposição 9 desta parte, e não reconheço nenhum outro afeto primário além destes três, pois mostrarei na sequência que os restantes se originam deles". Cf. ESPINOSA, Baruch. Ética. Trad. Grupo de Estudos Espinosanos (USP). São Paulo: Edusp, 2015, pags. 257.

${ }^{68}$ CHAUI,M, A Nervura do Real - Vol. 2. São Paulo : Cia das Letras, 2016., p. 178.
} 
escombros da opressão que recai sobre uma parte considerável do povo. Se as democracias capitalistas são marcadas por esse mal, não é certamente por serem democracias, mas por serem capitalistas. Nelas, os grupos sociais que dominam o campo específico do poder (potestas) são, de um modo geral, aqueles que exercem também o poder econômico. Ora, o poder econômico, no capitalismo, tende a ser exercido sempre sob alguma forma de opressão, já que se estrutura sobre uma necessária assimetria: o desejo alegre e passional de possuir bens é mais satisfeito para a menor parte da sociedade, enquanto a massa do povo (trabalhadores) só pode ter esse desejo satisfeito dentro de certos limites do necessário à conservação de si (sobrevivência). Não apenas esta assimetria, esta desigualdade estrutural, pode chegar a ser vista e sentida como injusta em si, como também podem ser vistos e sentidos como injustos as estruturas e mecanismos do Estado, que deve exercer sobre os "descontentes" a sua força ou "violência legítima" para conservar a ordem pública em nome, afinal, do desejo natural de conservar a paz e a segurança que garantem o exercício da vida. $\mathrm{O}$ trabalho - teórico e prático - dos revolucionários sempre foi o de dar visibilidade à injustiça e à desigualdade estrutural, mostrando seu caráter histórico determinado, no lugar de sua naturalização ou destinação metafísica.

A desigualdade estrutural nas democracias capitalistas cinde o conatus político em dois grandes grupos. De um lado, aqueles que poderíamos chamar de "grupos privilegiados", que, numa linguagem marxiana, são os detentores privados dos meios de produção ou, nomeadamente, a burguesia econômica. De outro lado, aqueles que foram engendrados no mesmo movimento histórico de ascensão da burguesia: os trabalhadores, nomeadamente o proletariado industrial. Politicamente, são dois conatus distintos, porque os primeiros desejam conservar a ordem social e econômica, precisamente e na medida em que esta ordem favorece o conatus de cada um deles, individualmente; já os últimos desejam a mudança justamente pelo motivo contrário, e tendem a constituir um conatus coletivo em torno desse desejo comum. Se os "privilegiados" não chegam a constituir um conatus propriamente coletivo, é porque o modo de vida econômico sobre o qual se assentam não favorece esse gesto constituinte: o capitalismo é intrinsecamente um sistema competitivo e, portanto, individualista $^{69}$. O conatus da chamada "burguesia", entretanto, ganha os contornos do

\footnotetext{
${ }^{69}$ Não se trata de um problema moral, evidentemente, mas de um sistema em que a competição se dá tanto no nível da produção quanto no nível dos mercados consumidores. Essa competição é sempre cada vez maior, porque a sobrevivência das instituições privadas de produção e de comércio depende dela. As chamadas "fusões" não são evidentemente formas de cooperação solidária entre empresas, mas antes estratégias para melhor competirem no capitalismo avançado, marcado pela hiperconcentração da renda e da propriedade privada.
} 
coletivo em momentos de luta contra os trabalhadores: é um conatus negativo e reativo, por assim dizer, porque não se caracteriza pela união de desejos comuns em torno de algo positivo, mas apenas com vistas a combater o grupo social que o ameaça enquanto tal. $\mathrm{Na}$ ausência dessa ameaça, os conatus dos privilegiados se pulverizam, se isolam, cada qual buscando seu útil próprio ${ }^{70}$.

Disso não se segue, porém, que, do outro lado, os trabalhadores constituam um grupo social compacto, fraterno, orientado apenas por ações e aspirações coletivas, em oposição ao individualismo e egoísmo dos grupos privilegiados. Se eles tendem a formar um conatus coletivo, enquanto trabalhadores, não é senão porque se encontram numa mesma situação que enfraquece seus conatus, diminui sua potência de existir, na dinâmica política e econômica. E sua luta contra uma tal situação é fadada ao fracasso, se for levada a cabo individualmente. A experiência política moderna mostra que aos trabalhadores não resta outra alternativa senão a luta coletiva. A essa luta os grupos sociais mais favorecidos, nas democracias capitalistas, impõem limites claros, e esses limites são aqueles que definem até onde os trabalhadores podem "marchar", isto é, em que medida seus atos e manifestações podem ser considerados legais e democráticos. Para além desses limites, seus gestos políticos são tomados como violentos, criminosos e, portanto, antidemocráticos.

Num momento histórico em que os ideais de revolução socialista parecem não se encontrar num horizonte próximo, o que resta aos trabalhadores menos favorecidos, nas democracias contemporâneas, é a luta pelo aprofundamento da própria democracia vigente, e isso na justa medida em que desejam conquistar direitos e mantê-los. Direitos sociais, direitos políticos, é sempre em nome desses direitos que os trabalhadores são os que realmente têm

\footnotetext{
${ }^{70}$ A questão que se poderia colocar aqui é: como é possível, então, que esse grupo social se mantenha enquanto grupo, se sua principal característica é precisamente a competição individual? Adam Smith, como se sabe, acreditou que toda uma sociedade de produtores, mercadores e consumidores se manteria por si só, através de uma "invisible hand", a "mão invisível" do mercado, famosa expressão que, no entanto, Smith utiliza apenas uma única vez em $A$ riqueza das nações. É a ideia de uma sociedade autorregulada justamente por meio dos egoísmos e interesses particulares. Cf. SMITH, A. A riqueza das nações. São Paulo: Nova Cultural, 1996, p. 438. A história mostrou que a sociedade capitalista não poderia manter-se por si só, sem o auxílio e a presença do Estado, não só como emissor e garantidor da moeda ou como garantidor dos contratos de compra e venda de mercadorias, sobretudo a mão de obra livre, mas também como regulador jurídico da concorrência entre as empresas, como garantidor, mas também ofertante, dos produtos do sistema financeiros (títulos, ações etc.). Ademais, nenhum economista sério, depois de Keynes, desconsidera o papel necessário do Estado na política monetária e de regulação dos juros. Keynes, como se sabe, preconizava três grandes funções ao Estado: incentivar o investimento, regular a oferta de emprego, ajustar esta oferta à "propensão ao consumo" e, na política de juros, mantê-los o mais baixo possível, em situações de grave desemprego (como era o caso nos anos 1930). KEYNES. J. Maynard. Teoria Geral do Emprego, do Juro e da Moeda. São Paulo: Saraiva, 2012, p. 339-349 (cap. 24). O que estamos querendo dizer é que o Estado é o principal fator de "coesão" da sociedade capitalista, no que concerne à burguesia ou aos indivíduos e grupos identificados com ela: de outra forma, deixada a si mesma, ela não poderia, provavelmente, manter-se de pé por muito tempo.
} 
interesse em manter e aprofundar a democracia. Os grupos economicamente privilegiados não são propriamente democráticos, porque aprofundar a democracia implica um ganho maior para os trabalhadores e um ganho menor para eles. Os "grandes" não são democráticos porque perdem com ela - ou pelo menos só são formalmente democráticos na justa medida em que o Estado de direito favorece sua condição privilegiada. Os trabalhadores tendem a ser democráticos porque na democracia eles podem conquistar direitos, ou seja, aumentar sua potência, individual e coletiva, de existir, de viver.

Aqui, a fórmula espinosana "direito é potência" - jus sive potentia - ganha seu sentido político e histórico mais evidente. Se democracia é criação e expansão de direitos - como pensava Claude Lefort ${ }^{71}$ - então ela é a forma política por excelência de expansão da potência da multitudo. O problema é que a multitudo não é um corpo uno, compacto e homogêneo: como todo corpo, ela é um todo complexo, internamente diferenciado. Sob o capitalismo, os grupos sociais são diversos, tão diversos que a divisão "burgueses e proletários", tomada em sua dualidade, quase ganha ares de abstração, ainda que conceitualmente seja correto dividir o social entre os que detém os meios de produção e os que não possuem outra coisa senão a força de trabalho para vender e sobreviver. Nessa complexa diferenciação interna, o social pode ser visto como um corpo em que algumas partes são favorecidas mais do que outras, mas o são justamente na medida em que essa outra são prejudicadas, desfavorecidas, coibidas em sua ação e diminuídas em sua potência (exploração, dominação etc.). Nesse sentido, o corpo político é necessariamente passional ${ }^{72}$. Há partes que são privilegiadas no jogo político e econômico, enquanto outras são desfavorecidas. Umas têm mais direitos que as outras. $\mathrm{Na}$ medida em que estas últimas lutam pela expansão de sua própria potência - isto é, de seus direitos - aquelas reagem num movimento contrário, uma vez que, sob o capitalismo, quando os grupos desfavorecidos conquistam, os grupos privilegiados perdem ou deixam de ganhar mais $^{73}$.

\footnotetext{
${ }^{71}$ Cf. LEFORT, Claude. "Direitos do homem e política", in: A invenção democrática: os limites da dominação totalitária. Belo Horizonte: Autêntica, 2011.

${ }^{72}$ Se a paixão, em Espinosa, define-se pela determinação exterior daquilo que um corpo é e faz, um corpo político cindido, dividido e marcado pela contrariedade entre suas partes (marca própria da condição passional), é necessariamente um corpo passivo. A política é o campo das paixões e, como se sabe, se os homens fossem todos e sempre racionais, não haveria necessidade da instituição do campo político...

${ }^{73}$ Aqui, nem é preciso recorrer a Marx. Pouco antes dele, David Ricardo já havia demonstrado que, no capitalismo, o aumento do lucro só é possível com a queda dos salários, e vice-versa. Em Princípios de economia política e tributação, no Capítulo VI, "Sobre os lucros", Ricardo escreve: "Sendo obrigado a pagar mais por essas mercadorias [i.e. os gêneros de primeira necessidade], o trabalhador teria de pedir salários maiores e qualquer fator que aumente os salários necessariamente reduz os lucros. Supondo, contudo, que o preço da seda, do veludo, do mobiliário e de outras mercadorias não exigidas pelo trabalhador, aumentasse em consequência de mais trabalho ser necessário para sua produção, isso não afetaria os lucros? Certamente não, pois nada os
} 
Tudo isso permite pensar o quanto é difícil e, em nossa época, rara, a emergência do desejo de transformação social radical e seu corolário, o amor pela revolução. Os fatores, como vimos, são por assim dizer de ordem intrínseca e extrínseca. Intrinsecamente, há sempre o desejo, o conatus humano, pelo qual o homem é determinado a perseverar na existência das mais diversas formas, e que é determinado, por sua vez, por modalidades de perseveração, elas mesmas historicamente determinadas, os modos de vida vigentes. Sob o modo de produção capitalista, os homens são determinados a perseverar num modo de vida, numa maneira de viver, que traz em seu bojo mil e um problemas, mil e uma formas de tristezas. Mas eles não insistiriam em perseverar por esse caminho, se não houvesse também, em meio a todas essas tristezas, mil e uma formas de alegrias possíveis, mil e uma formas de esperanças de consumo, ainda que, sob um olhar atento, elas não passem muitas vezes de esperanças vãs. O capitalismo não seria nada se não fosse o desejo daqueles que, no entanto, têm seu esforço em perseverar na existência desfavorecido ou coibido. São dominados, sua vida se inscreve no campo da servidão, mas são aquilo que Frédéric Lordon chamou de “dominados felizes” (dominés heureux) ${ }^{74}$. Extrinsecamente, há sempre as forças contrárias ao desejo de transformação cuja expressão máxima encontra-se no pensamento e na ação revolucionários. Há, antes de mais nada, a relação salarial, que é uma relação de dependência vital; mas há também as forças da ordem, que estão sempre aí para conter todo desejo de instituição de uma nova ordem, o novum institutum da multitudo. Este desejo é sempre possível, sempre latente, porque a "felicidade" dos "dominados felizes" é uma "felicidade" frágil, precária, e portanto pode sempre, a qualquer momento, ser quebrada, expondo-se às ilusões e fraquezas de suas próprias promessas.

6.

O prólogo do Tratado da Emenda se oferece como narrativa dramática de uma experiência afetiva que coloca a ordem comum de viver em questão. $\mathrm{O}$ embate entre vida e morte põe o modo de vida comum em xeque: é preciso, é necessário, é urgente encontrar uma alegria de outra ordem, uma nova modalidade de perseveração na existência, uma nova maneira que favoreça a vida e não a morte, a criação e não a destruição. No terreno da vida e da ação coletiva, os revolucionários dos séculos XIX e XX não fizeram outra coisa: diante das visíveis contradições do modo de produção capitalista - contradições cujas consequências são

afeta, salvo o aumento de salários. Sedas e veludos não são consumidos pelo trabalhador, logo não podem elevar os salários". Cf. RICARDO, David. Princípios de economia política e tributação. 3ä. ed. São Paulo: Nova Cultural, 1988, p. 62.

${ }^{74}$ LORDON, F. Capitalisme, désir et servitude. Paris: La fabrique éditions, 2010, p. 12. 
a morte e a destruição -, meditaram assiduamente sobre um novo modo de vida, nomeando-o socialismo ou comunismo ${ }^{75}$.

Mas nem a busca pela felicidade, a "alegria contínua e suprema", nem a luta pelo socialismo e o comunismo são as consequências históricas lógicas (necessárias) de uma vida contraditória. São objetivos supremos cuja condição é a transformação do desejo. Mas para além das experiências singulares e exemplares daqueles que um dia tiveram seu desejo transformado em desejo de verdadeira felicidade ou de revolução, o que nos resta, para que tenhamos, nós mesmos, nosso desejo redirecionado para um novo modo de vida? Precisamente o que alguns deles - Espinosa, num caso, Marx, no outro - nos legaram: a narrativa da experiência dramática e o pensamento que busca apreendê-la, num esforço de transformação da vida comum. A narrativa e a teoria, quando permanecem no tempo e no espaço, podem transformar desejos e reorientar ações ${ }^{76}$, desde que sejamos leitores “engajados" no mesmo drama de que elas falam. Nisto reside a importância de toda a tradição revolucionária, que, não obstante todos os acontecimentos dos últimos 50 anos, teve, no mínimo, o mérito de ser portadora do discurso revolucionário. É que não haverá revolução nenhuma, se não falarmos nela. Se a revolução não está no horizonte político, não podemos desejá-la. E se não a desejamos, não podemos amá-la. O amor pela revolução é o afeto político capaz de engendrar transformações movidas, não pelo ódio, mas pela alegria - posto que é um amor - de sabermos ser possível e desejável um novo modo de vida, contra as forças destrutivas e a dinâmica de morte do capitalismo.

Quando o fenômeno stalinista se tornou visível para todos, as esquerdas do mundo inteiro passaram da crítica à autocrítica, mas de certo modo deixaram-se levar, nesse gesto,

\footnotetext{
${ }^{75}$ Não é o caso, aqui, de entrar uma vez mais no debate sobre se estes termos nomeiam coisas diferentes, ou se o socialismo é a uma fase da revolução que precede a instituição do comunismo. Para nós o que importa é que ambos nomeiam o novum institutum coletivo, e isso basta para nossos propósitos.

76 No início de seu famoso ensaio Experiência e pobreza, Walter Benjamin fala-nos da experiência empobrecedora e emudecedora da Primeira Guerra: “[...] os combatentes tinham voltado silenciosos do campo de batalha. Mais pobres em experiências comunicáveis, e não mais ricos" (BENJAMIN, 1994, p. 114-115). Talvez a região do planeta a que observação de Benjamin menos se aplicava era a Rússia daquele período. Pouco antes do fim da guerra (1918), muitos soldados russos já estavam voltando para o país marcados por uma outra narrativa, a da esperança socialista, a das teorias revolucionárias. Muitos deles já haviam ido para a guerra levando na bagagem os acontecimentos da Revolução de 1905, e durante a guerra não estavam indiferentes ao que ocorria na Rússia. A experiência da guerra não terá para eles o efeito de uma afasia traumática: as vozes da revolução, a narrativa de um porvir libertário, os ecos das teorias revolucionárias sopravam em seus ouvidos e abriam na experiência de uma guerra sem sentido - a não ser os sons abstratos de expressões como "lutar pela nação" e "morrer pela pátria" - as brechas para se desejar, pensar e agir seguindo os rumos da revolução. Uma parte considerável dos soldados russos da Primeira Guerra teve uma outra experiência, diferente da de muitos combatentes dos outros países da velha Europa capitalista, uma experiência marcada pela narrativa da Revolução, já em germe em 1905, já em curso em fevereiro de 1917, e na qual eles terão papel decisivo. Muitos desses combatentes voltaram da guerra, não mais pobres "em experiência comunicáveis", mas "mais ricos".
} 
pelos velhos e sempre atuais mecanismos contrarrevolucionários da propaganda realizada pelas forças políticas e ideológicas do capital ${ }^{77}$. Esses mecanismos sempre trataram de fazer da revolução uma ideia triste, impotente, utilizando fórmulas hoje demasiado conhecidas: comunismo $=$ guerra civil, comunismo $=$ totalitarismo, $\mathrm{e}$, por fim, comunismo $=$ fracasso. $\mathrm{A}$ revolução se tornou uma tristeza, a palavra revolução praticamente desapareceu do sistema de circulação das ideias políticas, e a política empobreceu. Seria preciso fazer da ideia de revolução, novamente, uma ideia alegre, potente. Seria preciso sentir e experimentar, uma vez mais, o desejo e o amor pela revolução, a alegria de nos sabermos capazes de engendrar uma outra maneira de viver, muito melhor, o que quer que ela seja, qualquer que seja o nome que ela receba. O que não podemos é perseverar na servidão como se estivéssemos lutando por nossa liberdade.

\section{REFERENCIAS}

BENJAMIN, W. Experiência e pobreza. Magia, técnica, arte e política: ensaios sobre literatura e história da cultura. São Paulo: Brasiliense,1994

BENSAÏD, D. Marx, o intempestivo. Rio de Janeiro: Civilização Brasileira, 1999

CHAUÍ, M. A Nervura do Real: liberdade e imanência em Espinosa. Vol II - Liberdade. São Paulo : Companhia das Letras, 2016

ESPINOSA, B. Ética. Trad. Grupo de Estudos Espinosanos (USP). São Paulo: Edusp, 2015

ESPINOSA, B. Tratado da Reforma da Inteligência. Trad. de L. Teixeira. 2a . ed. São Paulo: Martins Fontes, 2004

ESPINOSA, B. Tratado Teológico-político. Trad. Diogo Pires Aurélio. São Paulo: Martins Fontes, 2003

KEYNES. J. Maynard. Teoria Geral do Emprego, do Juro e da Moeda. São Paulo: Saraiva, 2012

LEFORT, C. "Direitos do homem e política", in: A invenção democrática: os limites da dominação totalitária. Belo Horizonte: Autêntica, 2011

LORDON, F. Capitalisme, désir et servitude. Paris: La fabrique éditions, 2010

MAQUIAVEL, N. O príncipe. São Paulo: Martins Fontes, 2008

MARX, K. O Capital vol 1 - o processo de produção do capital. Trad. Rubens Enderle. São

\footnotetext{
${ }^{77}$ A propaganda contrarrevolucionária é tão antiga quanto as lutas revolucionárias dos trabalhadores. Quando os operários de Paris deram início, em 1871, à primeira experiência revolucionária de tomada do poder pelos trabalhadores, Adolphe Thiers não hesitou em utilizar balões para despejar folhetos sobre as cabeças dos camponeses, informando-os dos perigos que os proletários comunistas representavam para a tradição, a família e a propriedade privada da terra.
} 
Paulo : Boitempo, 2011

MARX, K; ENGELS, F. Manifesto Comunista. Coleção Avante! Lisboa : Edições Progresso, 19821982

NEGRI, A. A anomalia selvagem: potência e poder em Espinosa. São Paulo : Ed. 34, 1993

PACHUKANIS, E.B. Teoria Geral do Direito e Marxismo. São Paulo : Editora Acadêmica, 1988

RICARDO, David. Princípios de economia política e tributação. $3^{\mathrm{a}}$. ed. São Paulo: Nova Cultural, 1988

SMITH, A. A riqueza das nações. São Paulo: Nova Cultural, 1996

WEBER, Max. A ética protestante e o "espírito" do capitalismo. São Paulo: Companhia das Letras, 2003

Recebido: setembro/2018

Aprovado: novembro/2018 